The Free Internet Journal

for Organic Chemistry
Paper

Arkivoc 2017, part ii, 173-179

Organic Chemistry

\title{
Application of tris(trimethylsilyl) phosphite as a convenient phosphorus nucleophile in the direct synthesis of tetrasubstituted $\alpha$-aminophosphonic acids from ketimines
}

\author{
Bogdan Boduszek and Tomasz K. Olszewski* \\ Department of Organic Chemistry, Faculty of Chemistry, Wrocław University of Science and Technology, \\ Wybrzeże Wyspiańskiego 29, 50-370 Wrocław, Poland \\ Email: tomasz.olszewski@pwr.edu.pl
}

Dedicated to Prof. Jacek Młochowski on the occasion of his $80^{\text {th }}$ anniversary

Received 07-30-2016

Accepted 08-23-2016

Published on line $09-05-2016$

\section{Abstract}

The condensation of tris(trimethylsilyl) phosphite with various ketimines leads directly to tetrasubstituted $\alpha$ aminophosphonic acids. The presented reaction proceeds readily at room temperature and provides labile silylated esters of tetrasubstituted $\alpha$-aminophosphonic acids, as non-isolable reaction intermediates. Subsequent methanolysis of the latter provides the desired $\alpha$-aminophosphonic acids bearing an fully substituted $\alpha$-carbon in good overall yields as crystalline non-hygroscopic solids after simple recrystallization from a methanol-acetone mixture.nordstom

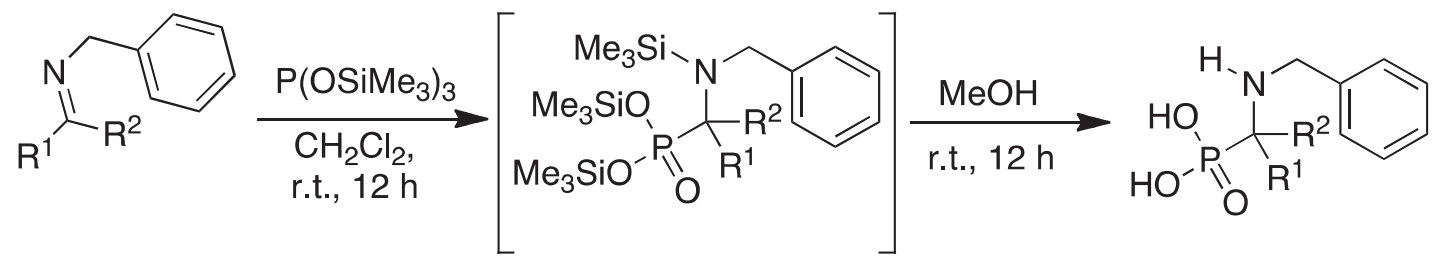

Keywords: Aminophosphonic acids, hydrophosphonylation, ketimines, ketones 


\section{Introduction}

$\alpha$-Aminophosphonic acids, as analogues of amino acids in which the carboxylic group is replaced by a phosphonic or related group (usually phosphonous or phosphinate) exhibit diverse biological properties and have found wide applications in many areas ranging from agriculture to medicine. ${ }^{1}$ The interesting properties of $\alpha$-aminophosphonic acids stem mainly from their structural analogy to natural carboxylic acids however equally important is the fact that the tetrahedral geometry of substituents around the phosphorus atom resembles the high-energy transition state of peptide bond hydrolysis. ${ }^{2}$ The latter feature is directly responsible for the biological activity of these compounds, mostly as enzyme inhibitors. When searching for new enzyme inhibitors, the $\alpha$-aminophosphonic acids are often incorporated in tailor-made peptide structures and those molecules are then tested for inhibitory activity. In that respect the use of tetrasubstituted $\alpha$ aminophosphonic acids as building blocks in the peptide synthesis is known to increase the rigidity of the peptide structure formed and thus improve its biological activity. ${ }^{3}$ The effective synthesis of tetrasubstituted $\alpha$-aminophosphonic acids is therefore very important from the point of view of the design and preparation of new and more active pharmaceuticals.

The most common protocol for the synthesis of $\alpha$-aminophosphonates relies upon the formation of the C$P$ bond via addition of phosphorus nucleophile to carbon-nitrogen double bond $(C=N)$ in imines or ketimines. In the case of the preparation of $\alpha$-aminophosphonates bearing an all-substituted $\alpha$-carbon however, this protocol is difficult to perform due to the poor electrophilic character of the carbon atom in the corresponding ketimines and the additional steric hindrance present at the reaction center. Because of that, the reaction usually requires prolonged heating of the reagents in a high boiling point solvent or requires the presence of additional reagents / catalysts to go to completion. ${ }^{4,5}$ Additionally, in order to obtain the tetrasubstituted $\alpha$ aminophosphonic acids, an additional synthetic step is required, namely, the hydrolysis of $\alpha$ aminophosphonates, which is usually performed again by prolonged heating of the substrate in the presence of a strong mineral acid, such as $\mathrm{HCl}$. Therefore in order to synthesize thermally unstable and delicate $\alpha$ aminophosphonates and phosphonic acids bearing an fully substituted $\alpha$-carbon such as e.g. heterocyclic derivatives, there is a need to replace the harsh reaction conditions with a milder protocol. It is well known that heterocyclic derivatives are a prevalent motif in natural compounds and are well known to play a pivotal role in the design of scaffolds and probes for pharmaceutical applications. ${ }^{6-8}$

As a part of our continuing interest in organophosphorus chemistry ${ }^{9-12}$ and particularly in the synthesis of new $\alpha$-functionalized phosphonates and corresponding phosphonic acids ${ }^{13-18}$ we decided to embark on a project aiming at development of an effective and mild protocol for the synthesis of tetrasubstituted $\alpha$ aminophosphonic acids. We report herein the addition of tris(trimethylsilyl) phosphite to various $\mathrm{N}$-benzyl ketimines as a very useful direct method, which affords desired $\alpha$-aminophosphonic acids with good overall yields and under mild reaction conditions. Pyridine and thiophene derived ketones were chosen as starting materials since small and simple heteroaromatics often have surprisingly complex biological properties and belong to one of the most important classes of compounds in medicinal chemistry. ${ }^{6-8}$ In turn, to demonstrate the versatility of the method we also applied it to ketimines derived from aliphatic ketones. Importantly, the use of benzylamine for the synthesis of ketimines allowed us to easily deprotect the amine function by hydrogenolysis, yielding the tetrasubstituted $\alpha$-aminophosphonic acids with a free amine group ready for use in e.g. peptide synthesis. 


\section{Results and Discussion}

We began our studies with the preparation of appropriate ketimines. This was done by heating the ketones (aliphatic or heteroaromatic) with benzylamine in toluene at reflux $\left(110^{\circ} \mathrm{C}\right)$ in a Dean-Stark apparatus for $3 \mathrm{~h}$. After that time the solvent was removed on vacuum yielding the desired ketimines, which were used in the next step without further purification. Subsequently, the ketimines 1a-f were subjected for reaction with tris(trimethylsilyl) phosphite in dichloromethane at room temperature (Table 1). This reagent was conveniently prepared in situ by reaction of commercially available trimethyl phosphite $\left(\mathrm{P}(\mathrm{OMe})_{3}\right)$ with bromotrimethylsilane $\left(\mathrm{BrSiMe}_{3}\right)$ in a molar ratio 1:4, in dichloromethane at room temperature. ${ }^{19,20}$ Reaction of tris(trimethylsilyl) phosphite with ketimines 1a-f produced, in the first stage, the corresponding labile silylated esters of tetrasubstituted $\alpha$-aminophosphonic acids $2 a-f$ as reaction intermediates which were not isolated but, in the second step, were treated with methanol, as dealkylating (desilylating) agent, producing the desired crude $\alpha$-aminophosphonic acids 3a-f (Table 1). Analytically pure samples of the $\alpha$ aminophosphonic acids $3 a-f$ were obtained after simple recrystallization from methanol-acetone mixture.

Table 1. Reaction of ketimines 1a-f with tris(trimethylsilyl) phosphite

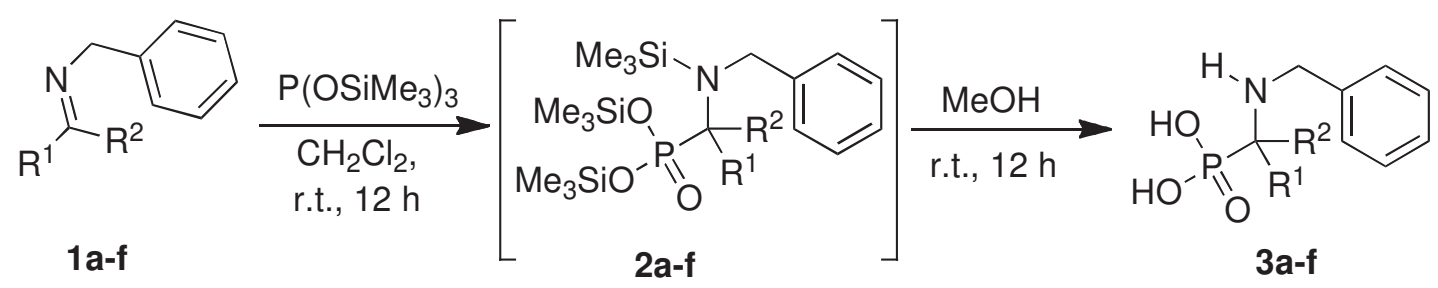

\begin{tabular}{ccccccc}
\hline Entry & $\mathbf{1}$ & $\mathrm{R}^{1}$ & $\mathrm{R}^{2}$ & $\mathbf{2}^{\mathrm{b}}$ & $\mathbf{3}$ & Yield (\%) $^{\text {a }}$ \\
\hline 1 & $\mathbf{1 a}$ & $\mathrm{Me}$ & $\mathrm{Me}$ & $\mathbf{2 a}$ & $\mathbf{3 a}$ & 61 \\
2 & $\mathbf{1 b}$ & $\mathrm{Me}$ & $\mathrm{Et}$ & $\mathbf{2 b}$ & $\mathbf{3 b}$ & 43 \\
3 & $\mathbf{1 c}$ & 2-Pyridyl & $\mathrm{Me}$ & $\mathbf{2 c}$ & $\mathbf{3 c}$ & 34 \\
4 & $\mathbf{1 d}$ & 3-Pyridyl & $\mathrm{Me}$ & $\mathbf{2 d}$ & $\mathbf{3 f}$ & 31 \\
5 & $\mathbf{1 e}$ & 4-Pyridyl & $\mathrm{Me}$ & $\mathbf{2 e}$ & $\mathbf{3 g}$ & 35 \\
6 & $\mathbf{1 f}$ & 2-Thienyl & $\mathrm{Me}$ & $\mathbf{2 f}$ & $\mathbf{3 h}$ & 43 \\
\hline
\end{tabular}

${ }^{\mathrm{a}}$ Isolated overall yield. ${ }^{\mathrm{b}}$ Not isolated.

The described above method presents a substantial improvement in the direct synthesis of $\alpha$ aminophosphonic acids bearing a fully substituted $\alpha$-carbon, especially derivatives containing fragile moieties such as heterocyclic systems. The in situ generated tris(trimethylsilyl) phosphite was found to be a good nucleophile toward the ketimines. The presence of a bulky trimethylsilyl group in the formed phosphonate or phosphonite-like ester increases the power of such a nucleophile due to formation of a stable, threecoordinated phosphorus moiety with a free electron pair at phosphorus. Also, absence of the possibility for tautomerization in the formed three-coordinated, silylated phosphorus ester into less nucleophilic fourcoordinated phosphonate-like ester, additionally secure the nucleophilic character of the applied reagent. Application of this nucleophile in the present case of the direct synthesis of the tetrasubstituted $\alpha$ aminophosphonic acids enabled the reaction to proceed readily at room temperature and produced the desired products in good overall yields. It has to be noted, that the heterocyclic derivatives synthesised here, 
containing of pyridine $3 \mathrm{c}-\mathrm{g}$ and thiophene $3 \mathrm{~h}$ units, are reported for the first time.

In order to obtain the target $\alpha$-aminophosphonic acids with a free amino group, as potentially useful building blocks for application in e.g. peptide synthesis, we decided to assess the deprotection of obtained $N$ benzyl derivatives of phosphonic products on the representative example of $\mathbf{3 c}$. Due to the presence of a benzyl group in the labile heterocyclic products, the deprotection of the amine could be carried out under very mild conditions ( $\mathrm{Pd} / \mathrm{C}(10 \mathrm{~mol} \%), 1$ eq. $\mathrm{HCl}(38 \%$ aq. $\left.), \mathrm{H}_{2}\right)$. A sample of $\alpha$-aminophosphonic acid $3 \mathrm{c}$ was dissolved in methanol and then $\mathrm{Pd} / \mathrm{C}$ (10 mol\%) was added followed by addition of 1 eq. of $\mathrm{HCl}(38 \%$ aq. solution). The resulting reaction mixture was vigorously stirred for $3 \mathrm{~h}$ under a hydrogen atmosphere. After filtration of the reaction mixture through the Celite the desired free $\alpha$-aminophosphonic acid 4 was obtained in $85 \%$ yield by evaporation of the filtrate and recrystallization of the crude product from ethanol-diethyl ether mixture (Scheme 1).
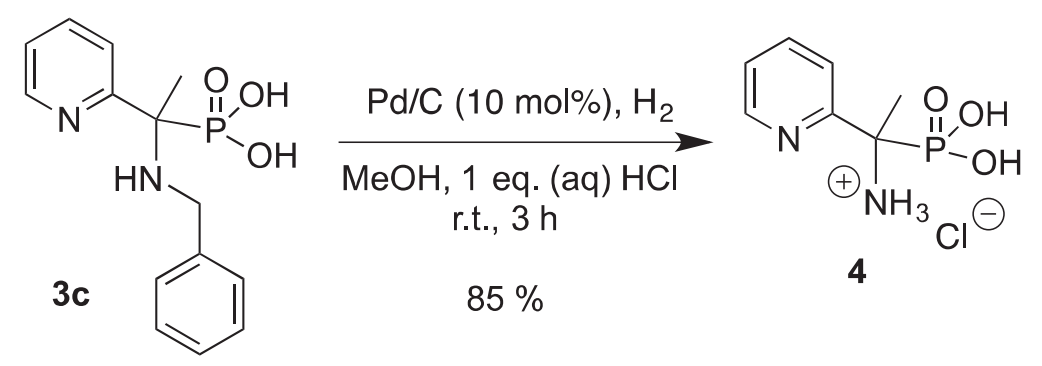

Scheme 1. Synthesis of 2-pyridyl-containing tetrasubstituted $\alpha$-aminophosphonic acids 4 by hydrogenolysis of $\mathrm{N}$-benzyl derivative $\mathbf{3 c}$.

\section{Conclusions}

We have reported above a very mild and effective protocol for the synthesis of tetrasubstituted $\alpha$ aminophosphonic acids by means of nucleophilic addition of tris(trimethylsilyl) phosphite, generated in situ, as a very reactive phosphorus nucleophile, to ketimines derived from benzylamine and various ketones. The reactions proceeded at room temperature and produced, in the first stage, the corresponding silylated esters of tetrasubstituted $\alpha$-aminophosphonic acids, which after treatment with methanol underwent desilylation and transformation into the desired $\alpha$-aminophosphonic acids with good overall yields. Additionally, the use of benzylamine in the described protocol allowed us to easily deprotect the amine functionality and obtain the target $\alpha$-aminophosphonic acids with a free amino group, that may be of interest as building blocks for e.g. peptide synthesis and the preparation of new enzyme inhibitors.

\section{Experimental Section}

General. ${ }^{1} \mathrm{H}(600 \mathrm{MHz}),{ }^{13} \mathrm{C}(150 \mathrm{MHz})$ and ${ }^{31} \mathrm{P}(243 \mathrm{MHz}) \mathrm{NMR}$ spectra were recorded on a Bruker Avance II $(600 \mathrm{MHz})$ spectrometer. Chemical shifts $(\delta)$ are reported in parts per million relative to internal tetramethylsilane $\left(\mathrm{Me}_{4} \mathrm{Si}, \delta 0.0\right)$ for ${ }^{1} \mathrm{H}$ NMR. Coupling constants $(J)$ are reported in Hertz. HRMS analyses were performed on LCT Premier XE Waters apparatus, on mode ESI+ (TOF MS ES+). Reported melting points are uncorrected. All reagents were used as received from the commercial supplier. All reactions were carried out 
in air. All solvents for extractions and reactions were technical grade and were dried before use using standard techniques.

Synthesis of tetrasubstituted $\mathbf{N}$-benzyl- $\alpha$-aminophosphonic acids $3 a-f$. General procedure. To a solution of $\mathrm{P}(\mathrm{OMe})_{3}(8.25 \mathrm{mmol})$ in dichloromethane $(25 \mathrm{~mL})$ was added fresh bromotrimethylsilane $(33 \mathrm{mmol})$. The tris(trimethylsilyl) phosphite solution thus generated was added to the appropriate ketimine $(8.25 \mathrm{mmol})^{21}$ dissolved in dichloromethane $(10 \mathrm{~mL})$. The resulting reaction mixture was stirred at room temperature for 12 $\mathrm{h}$. After that time solvent was removed in vacuum and the remaining viscous solid was treated with methanol $(10 \mathrm{~mL})$ and the solution stirred for an additional $12 \mathrm{~h}$ at room temperature. Next the solvent was removed in vacuum and the remaining crude $N$-benzyl- $\alpha$-aminophosphonic acids were crystallized from a mixture of methanol and acetone.

2-[(Benzylamino)propan-2-yl]-phosphonic acid (3a). ${ }^{22} \mathrm{~A}$ white solid (1.15 g, 61\%), mp 186-187 ${ }^{\circ} \mathrm{C} .{ }^{1} \mathrm{H} \mathrm{NMR}$ $\left(600 \mathrm{MHz}, \mathrm{D}_{2} \mathrm{O}\right): \delta_{\mathrm{H}} 1.50\left(\mathrm{~d}, J_{H P} 13.2 \mathrm{~Hz}, 6 \mathrm{H}\right), 4.31(\mathrm{~s}, 2 \mathrm{H}), 7.36-7.40(\mathrm{~m}, 5 \mathrm{H}) .{ }^{31} \mathrm{P}$ NMR $\left(243 \mathrm{MHz}, \mathrm{D}_{2} \mathrm{O}\right): \delta_{\mathrm{p}} 15.45$ (s). HRMS calcd for $(\mathrm{M}+\mathrm{H}) \mathrm{C}_{10} \mathrm{H}_{17} \mathrm{NO}_{3} \mathrm{P}: 230.0946$; found 230.0950 .

2-[(Benzylamino)butan-2-yl]-phosphonic acid (3b). ${ }^{22} \mathrm{~A}$ white solid (850 mg, 43\%), mp $180-181{ }^{\circ} \mathrm{C} .{ }^{1} \mathrm{H}$ NMR $\left(600 \mathrm{MHz}, \mathrm{D}_{2} \mathrm{O}\right): \delta_{\mathrm{H}} 0.98\left(\mathrm{t}, J_{H H} 7.5 \mathrm{~Hz}, 3 \mathrm{H}\right), 1.41\left(\mathrm{~d}, J_{H P} 13.8 \mathrm{~Hz}, 3 \mathrm{H}\right), 1.88-1.91(\mathrm{~m}, 2 \mathrm{H}), 4.21\left(\mathrm{dd}, J_{H H} 12.6 \mathrm{~Hz}\right.$, $2 \mathrm{H})$, 7.38-7.41 (m, 5H). ${ }^{31} \mathrm{P}$ NMR $\left(243 \mathrm{MHz}, \mathrm{D}_{2} \mathrm{O}\right): \delta_{\mathrm{P}} 15.41$ (s). HRMS calcd for $(\mathrm{M}+\mathrm{H}) \mathrm{C}_{11} \mathrm{H}_{19} \mathrm{NO}_{3} \mathrm{P}: 244.1103$; found 244.1100.

1-[(Benzylamino)-1-(pyridin-2-yl]ethylphosphonic acid (3c). A white solid (816 mg, 34\%), mp $208-210{ }^{\circ} \mathrm{C} .{ }^{1} \mathrm{H}$ NMR $\left(600 \mathrm{MHz}, \mathrm{D}_{2} \mathrm{O}\right): \delta_{H} 1.92\left(\mathrm{~d}, J_{H P} 13.2 \mathrm{~Hz}, 3 \mathrm{H}\right), 3.87\left(\mathrm{~d}, J_{H H} 10.8 \mathrm{~Hz}, 1 \mathrm{H}\right), 4.18\left(\mathrm{~d}, J_{H H} 12.6 \mathrm{~Hz}, 1 \mathrm{H}\right), 7.36-7.39$ $(\mathrm{m}, 5 \mathrm{H}), 7.41-7.43(\mathrm{~m}, 1 \mathrm{H}), 7.56-7.58(\mathrm{~m}, 1 \mathrm{H}), 7.83-7.86(\mathrm{~m}, 1 \mathrm{H}), 8.56-8.58(\mathrm{~m}, 1 \mathrm{H}) .{ }^{13} \mathrm{C} \mathrm{NMR}\left(150 \mathrm{MHz}, \mathrm{D}_{2} \mathrm{O}\right)$ : $\delta_{C} 17.5,43.0,65.4\left(\mathrm{~d}, J_{\mathrm{C}-\mathrm{P}} 132 \mathrm{~Hz}\right), 122.5,123.5,129.0,129.5,131.4,133.2,138.1,148.2,154.1 .{ }^{31} \mathrm{P} N M R(243$ $\left.\mathrm{MHz}, \mathrm{D}_{2} \mathrm{O}\right): \delta_{\mathrm{p}} 11.08(\mathrm{~s})$. HRMS calcd for $(\mathrm{M}+\mathrm{H}) \mathrm{C}_{14} \mathrm{H}_{18} \mathrm{~N}_{2} \mathrm{O}_{3} \mathrm{P}: 293.1055$; found 293.1059.

1-[(Benzylamino)-1-(pyridin-3-yl)]ethylphosphonic acid (3d). A white solid (740 mg, 31\%), mp $224-225{ }^{\circ} \mathrm{C} .{ }^{1} \mathrm{H}$ NMR $\left(600 \mathrm{MHz}, \mathrm{D}_{2} \mathrm{O}\right): \delta_{\mathrm{H}} 2.03\left(\mathrm{~d}, J_{H P} 12.6 \mathrm{~Hz}, 3 \mathrm{H}\right), 4.30\left(\mathrm{dd}, J_{\mathrm{HH}} 13.2 \mathrm{~Hz}, 2 \mathrm{H}\right), 7.25-7.27(\mathrm{~m}, 5 \mathrm{H}), 7.90-7.93(\mathrm{~m}$, $1 \mathrm{H}), 8.60-8.62(\mathrm{~m}, 1 \mathrm{H}), 8.64-7.66(\mathrm{~m}, 1 \mathrm{H}), 8.80-8.82(\mathrm{~m}, 1 \mathrm{H}) .{ }^{13} \mathrm{C} N M R\left(150 \mathrm{MHz}, \mathrm{D}_{2} \mathrm{O}\right): \delta_{\mathrm{C}} 17.1,48.0,61.7\left(\mathrm{~d}, J_{\mathrm{C}-}\right.$ p $129.9 \mathrm{~Hz}), 127.1,128.8,129.2,130.0,130.4,137.3,143.5,144.0,144.8 .{ }^{31} \mathrm{P} N M R\left(243 \mathrm{MHz}, \mathrm{D}_{2} \mathrm{O}\right): \delta_{\mathrm{p}} 9.62(\mathrm{~s})$. HRMS calcd for $(\mathrm{M}+\mathrm{H}) \mathrm{C}_{14} \mathrm{H}_{18} \mathrm{~N}_{2} \mathrm{O}_{3} \mathrm{P}: 293.1055$; found 293.1060 .

1-[(Benzylamino)-1-(pyridin-4-yl]ethylphosphonic acid (3e). A white solid (840 mg, 35\%), mp 190-192 ${ }^{\circ} \mathrm{C} .{ }^{1} \mathrm{H}$ NMR $\left(600 \mathrm{MHz}, \mathrm{D}_{2} \mathrm{O}\right): \delta_{\mathrm{H}} 2.04\left(\mathrm{~d}, J_{H P} 12.6 \mathrm{~Hz}, 3 \mathrm{H}\right), 4.03$ (d, $\left.J_{H H} 13.2 \mathrm{~Hz}, 1 \mathrm{H}\right), 4.29$ (d, $\left.J_{H H} 13.2 \mathrm{~Hz}, 1 \mathrm{H}\right), 7.37-7.40$ $(\mathrm{m}, 5 \mathrm{H}), 8.03\left(\mathrm{~d}, J_{H H} 5.3 \mathrm{~Hz}, 2 \mathrm{H}\right), 8.63\left(\mathrm{~d}, J_{H H} 6.6 \mathrm{~Hz}, 2 \mathrm{H}\right) .{ }^{31} \mathrm{P} N M R\left(243 \mathrm{MHz}, \mathrm{D}_{2} \mathrm{O}\right): \delta_{\mathrm{P}} 9.42$ (s). HRMS calcd for $(\mathrm{M}+\mathrm{H}) \mathrm{C}_{14} \mathrm{H}_{18} \mathrm{~N}_{2} \mathrm{O}_{3} \mathrm{P}: 293.1055$; found 293.1056.

1-[(Benzylamino)-1-(thiophen-2-yl]ethyl)phosphonic acid (3f). A white solid (1.15 g, 47\%), mp $217-219{ }^{\circ} \mathrm{C} .{ }^{1} \mathrm{H}$ NMR $\left(600 \mathrm{MHz}, \mathrm{DMSO}-d_{6}\right): \delta_{H} 1.70\left(\mathrm{~d}, J_{H P} 15.0 \mathrm{~Hz}, 3 \mathrm{H}\right), 3.78\left(\mathrm{dd}, J_{H H} 12.0 \mathrm{~Hz}, 2 \mathrm{H}\right), 6.90-6.93(\mathrm{~m}, 1 \mathrm{H}), 7.18-7.27$ $(\mathrm{m}, 7 \mathrm{H}) .{ }^{13} \mathrm{C}$ NMR $\left(150 \mathrm{MHz}\right.$, DMSO- $\left.d_{6}\right): \delta_{\mathrm{C}} 25.4,44.8,62.1$ (d, $\left.J_{C P} 132.6 \mathrm{~Hz}\right), 130.1,131.2,131.5,132.0,132.8$, 134.7, 136.6, 136.9. ${ }^{31}$ P NMR (243 MHz, DMSO- $\left.d_{6}\right): \delta_{\mathrm{p}} 7.63$ (s). HRMS calcd for $(\mathrm{M}+\mathrm{H}) \mathrm{C}_{13} \mathrm{H}_{17} \mathrm{NO}_{3} \mathrm{PS}: 298.0667$; found 298.0670 .

Preparation of tetrasubstituted $\alpha$-aminophosphonic acid 4 with a free amino group

1-Amino-1-(pyridin-2-yl)ethyl)phosphonic acid hydrochloride (4). To a solution of (1-(benzylamino)-1(pyridin-2-yl)ethyl)phosphonic acid 3c (400mg, $1.37 \mathrm{mmol})$ in methanol $(30 \mathrm{~mL})$ was added $\mathrm{HCl}(1.37 \mathrm{mmol}$ of $38 \%$ aq. solution) and $\mathrm{Pd} / \mathrm{C}(10 \mathrm{~mol} \%)$. The reaction mixture was stirred vigorously and a stream of $\mathrm{H}_{2}$ was gently bubbled through the solution for $3 \mathrm{~h}$. After that time the reaction mixture was filtered thorough the pad of Celite and the filtrate was evaporated to dryness in vacuum. The crude product was crystallized from mixture ethanol - diethyl ether yielding the (1-amino-1-(pyridin-2-yl)ethyl)phosphonic acid hydrochloride (4) as a white solid (270 mg, 85\%), mp 227-229 ${ }^{\circ} \mathrm{C} .{ }^{1} \mathrm{H}$ NMR $\left(600 \mathrm{MHz}, \mathrm{D}_{2} \mathrm{O}\right): \delta_{\mathrm{H}} 1.83\left(\mathrm{~d}, J_{H P} 12.27 \mathrm{~Hz}, 3 \mathrm{H}\right), 7.75-$ 
$7.77(\mathrm{~m}, 1 \mathrm{H}), 7.88\left(\mathrm{~d}, J_{H H} 7.9 \mathrm{~Hz}, 1 \mathrm{H}\right), 8.31-8.33(\mathrm{~m}, 1 \mathrm{H}), 8.57\left(\mathrm{~d}, J_{H H} 4.7 \mathrm{~Hz}, 1 \mathrm{H}\right) .{ }^{13} \mathrm{C} \mathrm{NMR}\left(150 \mathrm{MHz}, \mathrm{D}_{2} \mathrm{O}\right): \delta_{\mathrm{C}}$ 19.4, 57.8 (d, $J_{C P} 133 \mathrm{~Hz}$ ), 124.2, 126.2, 129.0, 146.4, 151.2. ${ }^{31} \mathrm{P}$ NMR (243 MHz, $\left.\mathrm{D}_{2} \mathrm{O}\right): \delta_{\mathrm{p}} 9.38$ (s). HRMS calcd for $(\mathrm{M}+\mathrm{H}) \mathrm{C}_{7} \mathrm{H}_{12} \mathrm{~N}_{2} \mathrm{O}_{3} \mathrm{P}$ : 203.0586; found 203.0588 .

\section{Acknowledgements}

Funding from a statutory activity subsidy from the Polish Ministry of Science and Higher Education for the Faculty of Chemistry, Wrocław University of Science and Technology, is acknowledged.

\section{References and Notes}

1. Berlicki, Ł.; Kafarski, P. Curr. Org. Chem. 2005, 9, 1829-1850 and references cited therein. http://dx.doi.org/10.2174/138527205774913088

2. Mucha, A.; Kafarski, P.; Berlicki, Ł. J. Med. Chem. 2011, 54, 5955-5980 and references cited therein. http://dx.doi.org/10.1021/jm200587f

3. Cervera-Villanueva, J. M. J.; Viveros-Ceballos, J. L.; Linzaga-Elizalde, I.; Ordóñez, M. J. Peptide Sci. 2016, 22, 70-75.

http://dx.doi.org/10.1002/psc.2841

4. For a comprehensive review see: Ordóñez, M.; Sayago, F. J.; Cativiela, C. Tetrahedron 2012, 68, 63696412 and references cited therein. http://dx.doi.org/10.1016/j.tet.2012.05.008

5. Olszewski, T. K. Synthesis 2014, 46, 403-429 and references cited therein.

http://dx.doi.org/10.1055/s-0033-1338588

6. Garcia-Castro, M.; Zimmermann, S.; Sankar, M. G.; Kumar, K. Angew. Chem. Int. Ed. 2016, 55, 2-22 http://dx.doi.org/10.1002/anie.201508818

7. Baumann, M.; Baxendale, I. R. Beilstein J. Org. Chem. 2013, 9, 2265-2319. http://dx.doi.org/10.3762/bjoc.9.265

8. Baumann, M.; Baxendale, I. R.; Ley, S. V.; Nikbin, N. Beilstein J. Org. Chem. 2011, 7, 442-495. http://dx.doi.org/10.3762/bjoc.7.57

9. Claudel, S.; Olszewski, T. K; Mutzenardt, P.; Aroulanda, C.; Coutrot, P.; Grison, C. Tetrahedron 2006, 62, 1787-1798.

\section{http://dx.doi.org/10.1016/j.tet.2005.11.051}

10. Grison, C.; Olszewski, T. K. Heteroatom Chem. 2008, 19, 461-469. http://dx.doi.org/10.1002/hc.20450

11. Olszewski, T. K.; Grison, C. Heteroatom Chem. 2010, 21, 139-147.

12. Olszewski, T. K.; Grison, C.; Bomont, C.; Coutrot, P. Ann. Soc. Entomol. Fr. 2011, 47, 45-54. http://dx.doi.org/10.1080/00379271.2011.10697695

13. Boduszek, B.; Olszewski, T.; Goldeman, W.; Konieczna, M. Phosphorus, Sulfur Silicon Relat. Elem. 2006, 181, 787-795.

http://dx.doi.org/10.1080/10426500500271865

14. Michalska, J.; Boduszek, B.; Olszewski, T. K. Heteroatom Chem. 2011, 22, 617-624. 
15. Boduszek, B. ; Olszewski, T. K. Synthesis 2011, 3, 437-442.

16. Palacios, F.; Olszewski, T. K.; Vicario, J. Org. Biomol. Chem. 2010, 8, 4255-4258. http://dx.doi.org/10.1039/c003004j

17. Olszewski, T. K.; Wojaczyńska, E.; Wieczorek, R.; Bąkowicz J. Tetrahedron: Asymmetry 2015, 26, 601607.

http://dx.doi.org/10.1016/j.tetasy.2015.04.012

18. Olszewski, T. K. ; Majewski, M. Tetrahedron: Asymmetry 2015, 26, 846-852.

http://dx.doi.org/10.1016/i.tetasy.2015.06.008

19. Boduszek, B. Pol. J. Chem. 2001, 75, 663-672.

20. Boduszek, B.; Olszewski, T.K.; Goldeman, W.; Grzegolec, K.; Blazejewska, P. Tetrahedron 2012, 68, 1223-1229.

http://dx.doi.org/10.1016/j.tet.2011.11.054

21. The ketimines used in this work were prepared by heating of the desired ketones (aliphatic or heteroaromatic) with benzylamine in toluene at reflux $\left(110^{\circ} \mathrm{C}\right)$ in a Dean-Stark apparatus for $3 \mathrm{~h}$. After that time the solvent was removed on vacuum yielding the desired ketimines, which were further used in the next step without purification.

22. Redmore, D. J. Org. Chem. 1978, 43, 996-997.

http://dx.doi.org/10.1021/jo00399a042 